\title{
MEDIA FRAMING ON ONLINE NEWS HEADLINES IN REGARDS TO THE GILETS JAUNES PHENOMENON
}

\author{
Fastira Dwiputri ${ }^{1}$, Myrna Laksman-Huntley ${ }^{2}$ \\ ${ }^{1,2}$ Program Studi Prancis, Fakultas Ilmu Pengetahuan Budaya Universitas Indonesia \\ fdfastira@gmail.com \\ laksman@ui.ac.id
}

\begin{abstract}
Gilets Jaunes massive protest in France was considered as the most serious crisis in the Fifth Republic since the protest of May 1968. The importance of the event was such that it generated serious controversy, which was widely reported and many French media competed to highlight the development of the action group. This study examines the headlines of the Gilets Jaunes phenomenon in two online news sites (LeFigaro.fr and Libération.fr) with different ideology. The analysis was carried out using theories of Le Querler's syntactic structure, Nida's meaning componential analysis, Dor \& Gattani's headline functionality, and Entman's media framing. The results show that left-wing media news titles framed Gilets Jaunes as evidence of the people's struggle, while the right-wing media framed Gilets Jaunes as an action that only caused riots and casualties. The constructed images of both media are carried out by highlighting selected viewpoints that are considered important and are supplemented by an explanation in the title. This study proves that media ideology can be reflected through news headlines.
\end{abstract}

Keywords: Media Framing, News Headlines, Online News, Gilets Jaunes, media ideology

\section{INTRODUCTION}

Gilets Jaunes is a social movement that was organized spontaneously to fight against the government's new policies regarding rising fuel prices and the public's decreasing purchasing power (Fabien, 2019). This major protest is considered to be the most serious crisis in the Fifth Republic since the events of May 1968 (Fabien, 2019). However, in the events, violence often occurred between demonstrators, journalists, and the police (Howard, 2018).

The Gilets Jaunes protest was held every week and each protest is called an Acte. Until November 2019, 53 Actes have been carried out regularly. Because of this routine, the number of demonstrators present at the actes is not the same every week. Nonetheless, Gilets Jaunes' drive to consistently carry out Actes with a clear schedule (although not always with a large crowd) that kept this movement in discussion throughout the year. The importance of the Gilets Jaunes movement also influenced the amount of coverage made by the media. Many online news sites even display Gilets Jaunes as one of their news categories to make it easier for readers to access updates on the Gilets Jaunes movement which is considered to contain elements that are very "saleable" in terms of reporting: continuity, polemic, and violence.

With the large number of online media sites today, competition in terms of creativity and speed of publication makes online news headlines appear to be more aggressive, excessive, and sometimes misleading (Reis, et al., 2015). This is considered dangerous because headlines do not only affect the first impression of someone reading the news, but also direct how readers perceive and remember the rest of the content associated with the headline (Ecker, et al., 2014). This relates to how the media functions as a reference to the public regarding what is important from an event and it can eventually redefine readers' opinions or perceptions.

The framing contained in the content is influenced by the ideology adopted by the 
media that publish it, even though in fact the requirements for a news are factual, accurate, and balanced (Rusadi, 2015). In France, the media are generally divided into two, namely conservative (right) and egalitarianism (left). According to research published on 17 May 2018 by the Pew Research Center on news media and political attitudes in France, each person chooses a different media site in search of news according to their own ideology. In responding to an incident, especially those related to government policies, the media will implicitly show their ideological position on the issue. This of course is related to the political orientation of the media and the government that issues policies. If the media's ideology agrees with the government actions, it will certainly issue news that is likely to show their support for the government.

The discussion regarding Gilets Jaunes has been reviewed several times, for example by Sebbah, Soillard, Thiong-Kay, Smyrnaios (2018) and Bonelli (2019). Studies that analyze news headlines have been done before: Adriano and Montejo (2018), Lombardi (2018), Ulum (2016), and Laras (2013). Likewise, there are researches on online news framing: Ecker et al (2014), Carter (2013), and Fauzi (2013). Mustika (2017) and Anggoro (2014) have reviewed framing comparisons conducted by two online media . In addition, Polackova (2018) and Hassan (2018) studied on the dismantling of media ideology and Tamba \& LaksmanHuntley (2020) have studied the utilization of the function accessory in the tracts on May 13 68. However, it is important to dismantle ideology and compare the framing carried out by different types of online media through a linguistic perspective that focuses on the structure and vocabulary usage in the displayed news titles. The final objective of this research is to prove the left and right French media framing differences about the Gilets Jaunes phenomenon. This study chooses the headlines from the LeFigaro.fr and Libération.fr news sites as data sources because they provide easy access to information about Gilets Jaunes through a choice of categories and these two media represent two different ideologies. The headlines chosen are related to events that occurred on 17 and 24 November 2018 and 1, 8, 15, and 22 December 2018, which are the dates for the Acte I-VI of Gilets Jaunes. This limitation is done after observing the decreasing number of demonstrators participating in the protests in Paris.

\section{RESEARCH METHODS}

This qualitative study analyzed collected data in three stages. First, dismantling the headlines' structure using Le Querler's (1994) syntactic theory to see the suitability of news headlines with good news headline theory according to the classification of news headlines' function by Dor (2003) and Gattani's (2005 both as quoted in Isani 2014). Secondly, Le Petit Robert dictionary (2019) is used to find word meanings in order to create meaning-component-tables using Nida's (1975) theory to compare several meanings between words in the headlines displayed by both media to see the depiction about the same elements. Finally, we relate all findings to interpret the media's ideology with Entman's theory (1991) of media framing .

\section{HEADLINES DEMONSTRATE DIFFERENCES BETWEEN MEDIA}

Quoting Dor (2003), Ecker (2014) states that the headline of a story functions to provide information and to persuade. On one hand, the headline must display the main information contained in the article, but on the other hand, the headline is the opening as well as the most important part of the news. Therefore, a headline should not only inform the reader about the content of the story, but also triggerring the desire to read the whole story. The news headline function can be seen as follows: the main function, macro function, and micro function (see table 1). 
Table 1. Division of beadline functions according to Dor \& Caniani

\begin{tabular}{|c|c|c|}
\hline $\begin{array}{l}\text { Main Function } \\
\text { (Der, 2003) }\end{array}$ & $\begin{array}{l}\text { Macro Function } \\
\text { (Guathani, 2005) }\end{array}$ & $\begin{array}{l}\text { Micro Function } \\
\text { (Dor, 2003) }\end{array}$ \\
\hline \multirow{4}{*}{$\begin{array}{l}\text { Negotialor hetwen } \\
\text { storids and readers }\end{array}$} & Informative & S'wmmance \\
\hline & \multirow[t]{2}{*}{ Indicative } & Ifighinght \\
\hline & & Attract \\
\hline & Eye-cavching & Select \\
\hline
\end{tabular}

The table shows that the headline has the main function as negotiator between story- reader. The headline based on Dor's statement has four micro functions, namely to summarise, to highlight, to attract, and to select. This function is complemented by Gattani's macro functions, namely informative, indicative (containing instructions), and eye-catching (Isani, 2014).

Headlines on the left and right media have a different pattern. This research found that the headlines on the left media happen to be more diverse than the right media.

\section{Diversity of Left Media Headlines}

The headline function proposed by Dor (2003) and Gattani (2005) focuses on presenting the headline which is designed attractively to highlight certain micro functions. As for the designation of these micro functions, the functions in the rules of language can be used as a marker of what is highlighted. For example, by looking at the presence or absence of verbs, adverbs, etc. we can compare whether the pattern and completeness of the function rules used by the two media produce titles with different macro and micro functions. Therefore, it is important for us to pay attention to the syntactic form of the headlines in order to see the way it presents words to the reader.

Most of the headlines about Gilets Jaunes published by the media Libération.fr (left) and LeFigaro.fr (right) use a colon (:). In this technique, a colon is used to connect speech. The first speech that is placed before the colon explains the topic or main point of the news, while the speech that is placed after the colon serves to clarify or provide further information about what will be conveyed about the news topic. However, on the headlines from the left media which are used as data sources, not all of them use a colon.

There are two headlines that use other

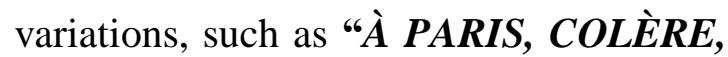
FLAMMES ET CONFUSION LORS DE LA MANIFESTATION DES GILETS JAUNES" published on December 1, 2018 and "Au quatrième samedi, une violence très contenue" published on December 8 2018. It can be seen how the left media uses all-capital type in one of its titles. This is certainly interesting because the large letters will further encourage readers to read the article.

Of the total headlines (which use a colon or not), there are two titles in the form of sentences, while the others are in the form of a collection of syntagmes (phrase).

Le Querler (1994) explains that syntagme is a collection of words arranged coherently around a word that is named as tête du syntagme (phrase head). The types of words that can become syntagmes nominal, pronominal, verbal, adjectival, and adverbial. Meanwhile, a collection of several syntagmes that depend on the pivot (centre) then form a sentence. The pivot in a sentence is usually a conjugated verb. However, pivots can also take the form of nouns, pronouns, infinitive verbs, and adverbs. For example, here we can see one of the headlines' structure by Libération.fr

"Au quatrième samedi, une violence très contenue"

'The fourth Saturday, contains high violence'

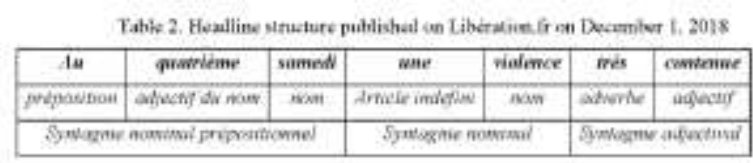

The headline is not a sentence, but just a group of syntagmes due to the absence of a pivot as a minimum requirement for a sentence. There are also 5 out of $6 \mathrm{left}$ media headlines have a similar structure to the syntagme set as shown in table 2. 
We can see a contrast in the following example.

“Gilets jaunes : à Paris, le soufflé (un peu) retombé"

'Gilets Jaunes: in Paris, the breath falls (a little)'

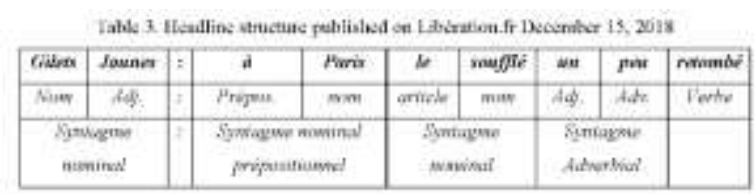

We can see on table 3 how the text after the colon, the syntagme set is completed with a verb as pivot. In the title, a colon separates the two pieces of text with the intention of making the reader to know easier the context being discussed, namely Gilets Jaunes. The text after the colon then clarifies what event is being discussed; this time in connection with Gilets Jaunes.

In a sentence that contains a pivot in the form of a verb, the syntagmes centered on the pivot are divided into two functions, namely les fonctions primaires (primary function) and les fonctions secondaires (secondary function) (Le Querler, 1994). In fonctions primaires, there are les fonctions primaires essentielles (i.e. sujet, complement d'objet, complement d'agent, complement $d u$ présentative, attributes, and locative) and fonctions primaires accessoires that can be categorized as expansion obligatoire containing complément circonstantiel (de temps, de manière, de moyen, d'accompagnement, de but, de cause, de consequence, de condition, de comparaison, de concession, d'opposition).

Expansion obligatoire is an expansion that must be added because this expansion serves to explain the verb that becomes the pivot; while fonctions secondaires or facultative expansion is not mandatory to add it because it will not change the meaning. This expansion can be given to provide additional explanations for nom, pronoun, adjective, and adverbe. That way, the explanation of table 3 can be developed as follows.

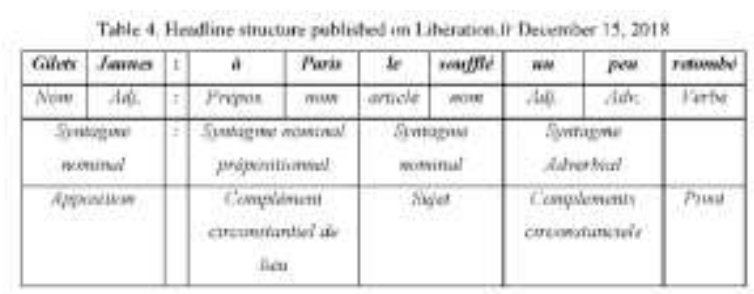

In this table, the text before the colon (Gilets Jaunes) functions as a subject; while, Gilets Jaunes and le soufflé are both subjects of sentences. Le souffle is another designation of Gilets Jaunes to which the news writer has given this title. Therefore, le soufflé is an apposition which Neveu (2000) describes as an explanation added to the nominal syntagme. This theory is clarified by Reverso Grammaire website stating that the apposition is related to the noun to complement or add information from the noun. Apposition has the same reality as the refererence nom. In this title, the nominal syntagme "le souffle" refers to the nominal syntagme "Gilets Jaunes" (le soufflé de Gilets Jaunes). The two syntagmes are not placed separately because in this title, Gilets Jaunes, which comes before the colon punctuation, also functions as a keyword in the news context.

In addition, in this table there is no facultative expansion in the sentence so that it shows that the sentence formed only consists of les fonctions primaires, which is indicated by the existence of subjects and pivots as les fonctions primaires essentielles, and the existence of complements circonstanciels as les fonctions primaires accessoires or expansion obligatoire.

However, the pivot in the sentence in this headline is dissipated. That is in the auxiliaire of the word "est" (the conjugation of être). Supposedly, the sentence is "à Paris, le soufflé est (un peu) 
retombé". The writer removes the word "est" to shorten the text but adds an accent to the letter "e" in the verb "retomber" (becoming retombé) so that it doesn't change the grammatical tense and overall meaning.

Through this explanation, it can be seen that the news titles in the left media were written in different formats such as the use of all capital letters and not using a colon in all of their titles. Moreover, the majority of these headlines are only a collection of syntagmes. The sentence form that is present in one of the headlines also has a dissipation of the pivot so that the headline becomes shorter and less standard. In relation to the theory headlines functions according to Dor (2005) and Gattani (2005), it can be concluded that the left media tries to highlight an indicative function in which it deliberately does not highlight the entire news content to be displayed in the title. In addition, the choice of words used in the headline text also tends to be eyecatching, such as violence, flammes (fire), colère (anger), une nuit agitée (a restless night), la révolte (rebellion), but accompanied in a descriptive way, so that it also highlights the informative function of the title.

\section{Uniformity of Right Media Headlines}

In contrast to Libération.fr, LeFigaro.fr headlines always use colons. Two of them have phrase form (sentence) after the colon as a complement to the first text portion.

$$
\begin{gathered}
\text { “"Gilets jaunes» : Ia manifestation } \\
\text { sur les Champs-Élysées a viré au } \\
\text { chaos” } \\
\text { “Gilets Jaunes» : The demonstration } \\
\text { at the Champs-Élysées turned } \\
\text { chaotic’ }
\end{gathered}
$$

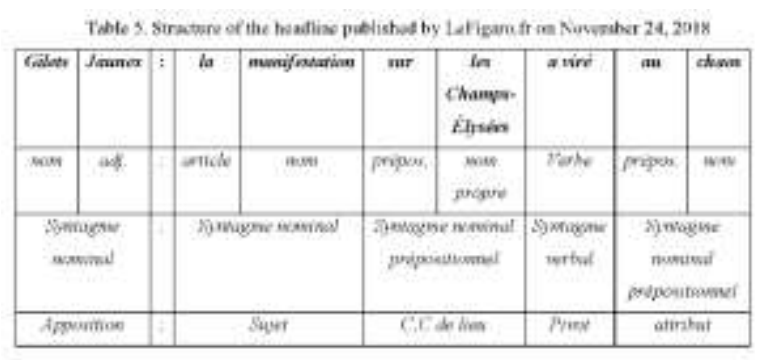

In the table, the text before the colon is a nominal syntagme functioning as apposition of the nominal syntagme "la manifestation" after the colon. Here, Gilets Jaunes and la manifestation refer to the same reality, the Gilets Jaunes demonstration. The placement of "Gilets Jaunes" before the colon aims to provide keywords regarding the context of the news item and la manifestation is used to prevent repetition in the title. Meanwhile, the other three syntagmes show the complement fonction circonstantiel de lieu, pivot, and attribut which are part of les fonctions primaires in the sentence.

Meanwhile, these four other headlines are using the same syntagme collection pattern as published by the left media.

We then concluded that both media's headlines are dominated by a collection of syntagmes. Even though there is a sentence form, the two media do not insert facultative expansion in the sentence. This shows that in the headline structure, the left and right media use the same strategy to adjust to the indicative news pointing theory because both aim to make news headlines easy to read quickly. In addition, both media also insert eye-catching words in each title to attract the attention of readers. The only thing that distinguishes left and right media is a colon in the headline. In this case, the left media seems to try to make a variety of titles and diverse looks while the right media homogenizes the form of its titles.

\section{PORTRAYAL OF GILETS JAUNES ACTIONS}

Based on the choice of vocabulary displayed mentioning the Gilets Jaunes 


\section{2 | JURNAL ILMU BUDAY}

movement in their title, both medias have their own strategies in building the image of Gilets Jaunes as an act.

Nida (1975) in Widyastuti (2016) states that the category of semantic components is divided into components of general meaning (in form of the smallest unit of meaning that is shared by a number of words but cannot be used as differentiator of meaning) and a component of the differentiating meaning (in form of the smallest unit of meaning in the same domain, but can be used as a meaning differentiator). A simple example to explain this category can be seen in the following table.

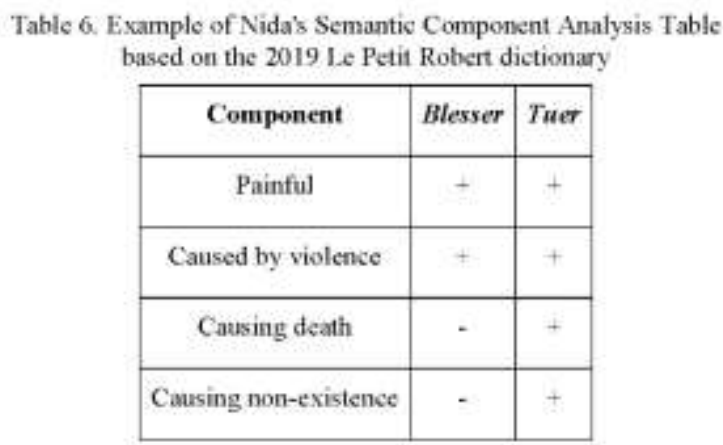

In the semantic domain of blesser and tuer, the meaning of both words can then be combined with the following features:

Tuer $+[$ Painful $]+[$ Caused by violence $]+[$ Causing death $]$

+ [Causing non-existence]

Blesser $+[$ Painful $]+[$ Caused by violence $]$

\section{Gilets Jaunes' Portrayal by Left Media}

In choosing a substitute for Gilets Jaunes, libération.fr uses several word variations such as la mobilisation, la révolte, and la manifestation. At the beginning of the appearance of Gilets Jaunes, namely in act I and II, the variations of the words chosen respectively contain strong semantic components, i.e., in "«Gilets jaunes»: la mobilisation en recul après« une nuit agitée »et 409 blessés", libération.fr chose the word la mobilisation to describe the Gilets Jaunes movement. From its semantic components, it shows that the writer seeks to define Gilets Jaunes with an action movement that connotes 'struggle', but is also synonymous with violence and something that involves many parties. The definition of mobilisation as an action that connotes struggle is supported by meaning components of opération (action or movement), a but ( having a specific goal), and bouger (showing movement). Meanwhile, the meaning of mobilization as a movement that is identical to violence and involves many parties is shown through the semantic component guerre (war or fighting against something) and armée (having troops).

Apart from mobilisation, "la révolte" in the title " "Ce n'est que le début de la révolte !»" also refers to Gilets Jaunes' action. La révolte contains a semantic component that connotes rebellion and is synonymous with violence. The element of rebellion in révolte is marked by the semantic component contre l'autorité (against authority), contre la régle (against the rule), and refus ( action to refuse). Meanwhile, the element of violence in the word révolte is indicated by the semantic component violente (violence).

Therefore, these headlines using two different words describing Gilets Jaunes (mobilisation and révolte), have a semantic component of action and an element of violence (shown through the guerre component in mobilisation and the violente component in révolte) with a specific purpose (indicated by the $a$ but component in mobilisation and the contre and refus component in révolte).

This indicates that in the headlines written by the left-wing media represented, the Gilets Jaunes movement at the beginning was described as a violent political action, involving many parties, to achieve a goal, namely rejecting certain authority. Then, in act III onwards, the left media began to use other designations such as la manifestation or 
did not give any designation at all (only explaining conditions). They only explain that the action always seems to contain riots represented by words such as colère (anger) and violence (violence).

\section{Gilets Jaunes Portrayal from Right Media}

Unlike libération.fr, at the beginning of its appearance, headlines of lefigaro.fr labelled the Gilets Jaunes movement with words related to "manifestation", i.e. in the headlines on the first three Actes: "«Gilets jaunes »: pres de 283,000 manifestants, une femme tuée en Savoie, des manifestants aux abords de l'Élysé", "«Gilets jaunes»: la manifestation sur les Champs-Élysées a viré au chaos", " "Gilets jaunes": 136,000 manifestants de Paris à Marseille".

These titles show that lefigaro.fr refers Gilets Jaunes' action directly to "la manifestation" or calls the Gilets Jaunes protestor "manifestant". From the word semantic components, manifestation refers to an organized public demonstration involving many participants (demonstration), défilé (parade) and réunion (gathering). Meanwhile, the organized element is characterized by the semantic component of organisé. This explanation shows that lefigaro.fr built the image of the Gilets Jaunes movement at the beginning of its appearance as a massive protest that was well organized, in accordance with the meaning components of manifestation.

The explanation of different vocabulary choices to mention the Gilets Jaunes movement in the headlines published by both media on the same date shows how a difference of one word in headlines can produce different images of the same situation. This difference is shown more clearly in the example of the following semantic component analysis table.

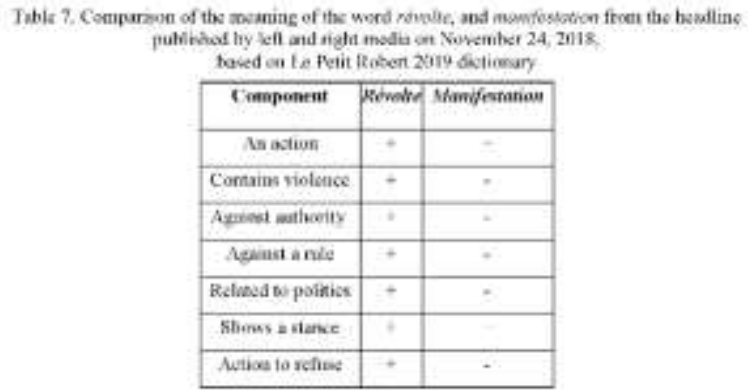

This table shows how both media want to build a different image of the Gilets Jaunes action on the same news date, namely 24 November 2018 when the Acte II of Gilets Jaunes happened. According to its semantic components, the word la révolte used by the left media implies the nature of a violent movement and shows its resistance to something. It is different from the right-wing media's manifestation which does not contain any elements of violence or resistance at all. Even so, both contain the meaning of an action showing a political stance. Therefore, there are similarities in the meanings of the both chosen words, but their images are different.

\section{MEDIA FRAMING BASED ON POLITICAL ORIENTATION}

The structure and words choice are part of the headline strategy to build a distinct framing of the whole Gilets Jaunes incident. Based on the explanation in the previous section, by using the word la manifestation in describing the Gilets Jaunes movement, lefigaro.fr seems to downplay the "struggle" portrayal. However, the imagery that arises from the selection of some parts of the headline is not sufficient to indicate the final framing of the headline. The headline as a whole needs to be studied in regards to how a certain word is used substituting Gilets Jaunes and compared to other vocabulary, what elements are highlighted in the title, and the comparison between titles published by both media on the same date regarding the same event.

Entman argues that framing theory uses two major dimensions, namely the selection of issues and the emphasis of certain 


\section{4 | JURNAL ILMU BUDAY}

aspects of the issue (1991 as quoted in Fauzi, 2013). The emphasis aims to make the information more meaningful, interesting, or more memorable for the reader. In framing analysis with the Entman model, news elements are divided into four (Carter, 2013) elements.

The four elements are: Defining Problems (the main frame that emphasizes how problems are defined by news makers based on their understanding), Diagnosing Causes (framing what or who is considered the actor of an event, which relates to how events are understood by the media and how it will affect what or who is the actor driving the problem), Make Moral Judgment (Justifying arguments on the two previous elements. Problems that have been defined and framed their causes are supported by providing moral judgments that thus strengthens the framing), and Treatment Recommendations (covering the newsmakers' purpose on what views to create as a reaction to the problems reported).

Due to the aim of headlines (easy to be read and understood), published headlines by both media are not too long. The "make moral judgment" element is difficult to find in the title, because news makers usually justify their arguments through the news content. In the analyzed news headlines, the elements of "defining problems", "diagnosis of causes", and "treatment recommendation" are found to frame the event based on how the headline defines the problem. We can observe the words describing Gilets Jaunes, and paired with words to describe the incident emphasized in the events. The way they frame their stories in the headline on 24 November 2018, for example, on the same event has differing compositions.

The title published by libération.fr: "Gilets jaunes à Paris:"Ce n'est que le début de la révolte!».", while the title published by lefigaro.fr: " "Gilets jaunes»: la manifestation sur les Champs-Élysées a viré au chaos". These two titles seem to respond to each other. In the title published in lefigaro.fr, the word chaos appears to emphasize that there was chaos at this event. The description of chaos in this title is intended to instantly shows the reader the level of danger posed by Gilets Jaunes' action. Meanwhile, in the title published by the leftist liberation.fr, the event is considered as "the beginning of the uprising carried out by the Gilets Jaunes activists.". Thus, it indicates that there is an end (goal) to which it is intended. This suggests that the right-wing media aims to build the image of Gilets Jaunes as chaotic and dangerous, while the left media wants to show that Gilets Jaunes is a valid act which wants to achieve a valid goal.

This explanation shows that framing cannot sufficiently be determined by unpacking the meaning of the title alone. The relationships between words that arise need to be thoroughly unified. In the previous section, liberation.fr referred to Gilets Jaunes with révolte, whose semantic component was harsher than the word manifestation used by lefigaro.fr because the word does not contain any element of violence. Considering Entman's framing theory, the words révolte and manifestation are the main frames that emphasize how news writers create problems. However, overall, the left media combines it with le début which describes an action that has a strong determination to achieve a goal. On the other hand, the right media that calls Gilets Jaunes an organised movement (based on the component of the meaning of manifestation) contrasts the subtle term with the chaotic and unsafe depiction of demonstrations to build the framing that Gilets Jaunes is a destructive riot.

This also shows that the strategy used by both media in their headlines is to insert either "dangerous" or "safe" vocabulary in the same text with an adjusted arrangement to channel their respective interests. According to Entman's framing theory, the newsmaker's intention of the perception that the left-wing media wishes to construct is shown by words that contain elements of violence and emotion, but the purpose of using these words is not to frame the protests badly, but rather to show that the fighting was to arouse the 


\section{5 | JURNAL ILMU BUDAY}

fighting spirit of Gilets Jaunes protesters and at the same time to indicate that this movement is a rebellion. The left media portrays Gilets Jaunes as a rebellion to indicate that there is an injustice that triggered them to fight for their desires, even if they are injured or losing their lives. This is in line with the left-wing media ideology that adheres to fighting for egalitarianism.

Meanwhile, the right media focuses more on the violence and chaos that occurred during the Gilets Jaunes demonstration or simply informing the number of Gilets Jaunes protesters. The highlighting of negative elements and the absence of words that trigger emotions to appear in headlines is done to create a framing that shows Gilets Jaunes as a barbaric action. Consequently, it discredits the struggle that was carried out by Gilets Jaunes activists to achieve equality by building an image that emphasizes the failure of Gilets Jaunes as an organized movement. This reflects the media stance that adheres to the right-wing ideology which upholds the stability of the nation. Therefore, its coverage is aimed at quelling the rebellion in order to maintain the status quo.

\section{CONCLUSION}

Every news media has an ideology that underlies the published content. Therefore, even though the necessary aim of news should be factual, accurate, and balanced, the reality that is represented in the media's stories is not always objective because it will inevitably be influenced by its ideology. Libération.fr and lefigaro.fr are two media with two different ideologies. Liberation.fr adheres to left-wing ideology that upholds the values of egalitarianism, while lefigaro.fr upholds the values of conservatism.

Structurally, there is no significant difference in the headlines between the left and right media. Both of them aim to make headlines that are easy and quick to read so that they emphasize the indicative function by using titles that are not too long. In addition, to attract readers' attention, both media utilize eye-catching words while in May 1968 tract variations of fonction accessoire played important role (Tamba \& Laksman Huntley, 2020). The difference between left and right media is only on the use of colon in the title. The left media becomes more diverse when compared to that of the right.

In the events framing, both media emphasize treatment recommendation element which indicates the newsmakers' intention as to what kind of view they want to construct as a reaction to the problems reported. In this case, both media use word choice strategy to build Gilets Jaunes image based on their respective ideology. The left media uses words with strong semantic components to replace "Gilets Jaunes". However, throughout the entire headline, the left media softens the tone of the headline by providing a more positive portrayal of images to give the impression that violence is not the focus and that protesters action has a purpose and should not be labelled as rebellion. On the other hand, the right media more often refers to Gilets Jaunes as an organized movement and contrasts those portrayals with chaotic and dangerous depictions of demonstrations to build a negative image of Gilets Jaunes as a destructive action.

The writing strategy of each media to channel its editorial ideology reflects the media ideology difference. Leftist media covers the Gilets Jaunes phenomenon in France as proof of people's voice and struggle to fight the injustices that befall them. This reflects the left-wing ideology that strives for values of equality in society. Meanwhile, in the right-wing media, the Gilets Jaunes phenomenon is framed as a barbaric action that only causes riots and casualties. This reflects the right-wing ideology that upholds the importance of national stability by downplaying the goals of the rebellion that was conveyed by Gilets Jaunes activists.

This shows the link between linguistic aspects, media framing, and media ideology representation. So far, media framing analysis is most often discussed with Entman theory as 
the scalpel, while media ideology is mostly exposed through Fairclough's theory of critical discourse analysis. The analysis of news headlines is mostly done to the extent of uncovering the meaning and purpose without relating it to media ideology. The presence of this research proves that in fact the results of the meaning behind the headlines can be analyzed more deeply, not merely to describe the strategy and function of the news headlines. Additionally, this research shows that media framing and ideology also need to be studied more linguistically.

By looking at the breaking down of news headlines through its structure and choice of words, the authors hope that the benefits of this process can be used and imitated by all levels of news consumers (both online and print). Especially in this era of modern mass media and clickbaits, it is hoped that they are not easily influenced by headlines that are misleading and are not related to the actual content. Additionally, it is hoped that consumers can be more aware of the political stance of the text which is sometimes obscured by headline-writing strategies.

\section{REFERENCES}

Adriano, T., \& Montejo, G. (2018). A critical discourse analysis of headlines in online news portals. Journal of Advances in Humanities and Social Sciences, 4(2). doi: 10.20474/jahss4.2 .2

Anggoro, A. (2014). Media, Politik dan Kekuasaan. Jurnal Aristo Vol.2 no.2. http://journal.umpo.ac.id/index.php/ari sto/article/viewFile/16/275

Bonelli, L. (2019). 'Gilets jaunes' shock the politicians.

https://www.researchgate.net/publicati on/330213874_Gilets_jaunes_shock_t he_politicians

Carter, M. J. (2013). The Hermeneutics of Frames and Framing: An Examination of the Media's Construction of Reality. SAGE,1-12. https://journals.sagepub.com/doi/pdf/1 $0.1177 / 2158244013487915$

Dor, D. (2003). On newspaper headlines as relevance optimizers. Journal of Pragmatics, 35(5), 695-721. doi:10.1016/s0378-2166(02)00134-0

Ecker, U. K., Lewandowsky, S., Chang, E. P., \& Pillai, R. (2014). The Effects of Subtle Misinformation in News Headlines. Journal of Experimental Psychology

Applied. https://www.researchgate.net/publicati on/264428502_The_Effects_of_Subtle _Misinformation_in_News_Headlines

Entman, R. (1991) Framing U.S. Coverage of International News: Contrasts in Narratives of the KAL and Iran Air Incidents. Journal of Communication, 41 6-27. https://doi.org/10.1111/j.14602466.1991.tb02328.x

Fabien, F. (2019). Mouvement des Gilets Jaunes : Résumé, Dates, Causes, Revendications. Accessed on November 192019 from: https://apprendre5minutes.wordpress.c om/2019/02/11/mouvement-des-giletsjaunes-resume-dates-causesrevendications/

Fauzi, A. (2013). Konstruksi Realitas Media Massa (Analisis Framing Pemberitaan Korupsi M. Nazaruddin di Harian Republika). Jakarta: UIN Syarif Hidayatullah. Skripsi.

Gattani, A. (2005). Maximum Entropy Discriminative Models for Headline Generation Accessed from: http://www.natland.cs.sfu.ca./research Project.php

GILETS JAUNES, les dates clés. (n.d.). Accessed on December 122019 from: https://www.liberation.fr/apps/2018/12 /gilets-jaunes-les-dates-cles/

Grammaire française : orthographe, syntaxe, participe passé, accord du verbe, ponctuation, conjugaison... (2013). Accessed on December 122019 from: 
http://grammaire.reverso.net/1_3_08_ Lapposition.shtml.

Hassan, A. (2018). Language, Media, and Ideology: Critical Discourse Analysis of Pakistani News Bulletin Headlines and Its Impact on Viewers. SAGE Open, 8(3), 215824401879261. doi: $10.1177 / 2158244018792612$

Howard, G. (4 Desember 2018). Everything you need to know about 'Les Gilets Jaunes' and the protests in France. Accessed on March 152019 from: https://www.abc.net.au/news/2018-1203/everything-you-need-to-knowabout-the-protests-in-france/10576834

Isani, S. (2014). Of headlines \& headlinese: Towards distinctive linguistic and pragmatic genericity. ASp,(60), 81102. doi:10.4000/asp. 2523

Laras, Sesulis. K. (2013). Struktur Sintaksis Judul-judul Berita dalam Surat Kabar Online Berbahasa Prancis. Depok: Universitas Indonesia.

Le Querler, N. (1994). Précis de syntaxe française. Caen: Presses Universitaires de Caen.

Lombardi, D. (2018). Critical Discourse Analysis of online News Headlines: A Case of the Stoneman Douglas High School Shooting. Swedia: Malmö University.

http://muep.mau.se/bitstream/handle/2 043/25801/Thesis_Lombardi\%20Dari a_Final.pdf?sequence $=1$

Mustika, R. (2017). Analisis Framing Pemberitaan Media Online mengenai Kasus Pedofilia di Akun Facebook. Jurnal Penelitian Komunikasi, 20(2). doi: 10.20422/jpk.v20i2.159

Neveu, F. (2000). L'apposition : Concepts, Niveaux, Domaines

Présentation. Langue

Française, (125), 3-17. www.jstor.org/stable/41559407

Pew Research Center. (17 Mei 2018). Facts on News Media \& Political Attitudes in France. Accessed on March 11 2019

from: http://www.pewglobal.org/factsheet/news-media-and-politicalattitudes-in-france/

Polackova, D. (2018). Media, Terrorism, and Political Ideologies: Framing of RightWing and Islamic Terrorism by Conservative and Liberal U.S. Media. Accessed on November 192019 from: https://www.researchgate.net/publicati on/323255155_Media_Terrorism_and _Political_Ideologies_Framing_of_Ri ght-

Wing_and_Islamic_Terrorism_by_Co nservative_and_Liberal_US_Media

Reis, J., et al. (2015). Breaking the News: First Impression Matter on Online News. ICWSM. Accessed on March 15 2019 from: https://arxiv.org/pdf/1503.07921.pdf

Rey, A. (2019). Le Petit Robert. Le Petit Robert. Paris: Le Robert.

Sebbah, B., Soillard, N., Thiong-Kay, L., \& Smyrnaios, N. (2018). Les Gilets Jaunes, des cadrages médiatiques aux paroles citoyennes. Accessed on November 192019 from: http://universitepopulairetoulouse.fr/sp ip.php?article1524.

Tamba, N \& Laksman-Huntley, M. (2020). Penggunaan Fungsi Pelengkap pada Kalimat dalam Tract Mei 1968. Jurnal Ilmu Budaya, 8 (1), 1-14. http://journal.unhas.ac.id/index.php/jib/ article/view/8922

Ulum, Ö. (2016). NEWSPAPER IDEOLOGY: A CRITICAL DISCOURSE ANALYSIS OF NEWS HEADLINES ON SYRIAN REFUGEES IN PUBLISHED NEWSPAPERS. Turkish Studies. doi: 11. 541-552.

10.7827/TurkishStudies.9930

Widyastuti, S. (2016). Componential analysis Of Meaning: Theory and Applications. Journal of English and Education, 4(1), 116-128. http://eprints.uny.ac.id/id/eprint/1174. 


\section{ATTACHMENT}

Libération.fr:

1. «Gilets jaunes» : la mobilisation en recul après «une nuit agitée» et 409 blessés (Published: November $17^{\text {th }} 2018$ )

2. Gilets jaunes à Paris : «Ce n'est que le début de la révolte !» (Published: November $24^{\text {th }} 2018$ )

3. À PARIS, COLÈRE, FLAMMES ET CONFUSION LORS DE LA MANIFESTATION DES GILETS JAUNES (Published: December $1^{\text {st }} 2018$ )

4. Au quatrième samedi, une violence très contenue (Published: December $8^{\text {th }} 2018$ )

5. Gilets jaunes : à Paris, le soufflé (un peu) retombé (Published: Desember $15^{\text {th }} 2018$ )

6. Gilets jaunes, acte VI : près de 40000 manifestants et 220 interpellations (Published: December $22^{\text {nd }} 2018$ )

\section{LeFigaro.fr:}

1. «Gilets jaunes» : près de 283.000 manifestants, une femme tuée en Savoie, des manifestants aux abords de l'Élysé (Published: November $17^{\text {th }} 2018$ )

2. «Gilets jaunes» : la manifestation sur les Champs-Élysées a viré au chaos (Published: November $24^{\text {th }} 2018$ )

3. «Gilets jaunes» : 136.000 manifestants de Paris à Marseille (Published: December $1^{\text {st }} 2018$ )

4. «Gilets jaunes»: les tweets de nos journalistes sur la mobilisation du 8 décembre (Published: December $8^{\text {th }}$ 2018)

5. Paroles de «gilets jaunes»: ce qu'ont entendu nos journalistes ce samedi 15 décembre (Published: Desember $15^{\text {th }}$ 2018)

6. «Gilets jaunes» acte VI : une mobilisation en nette baisse (Published: December $22^{\text {nd }} 2018$ ) 